\title{
When Losing Citizenship Is Fine. \\ Denationalisation and Permanent Expatriation
}

\author{
Jules Lepoutre \\ Université Côte d'Azur, LADIE, France
}

\begin{abstract}
Over the last few decades, only a few studies have assessed denationalisation as a way of terminating 'obsolescent' citizenship resulting from the long-term emigration of an individual. This mode of loss of citizenship seems prima facie more legitimate than citizenship revocation as a means of punishment, as it only represents the legal recognition of the disappearance of a genuine link between an individual and a state. This paper explores the legal status of this mechanism (both from international law and national legislation) and differentiates three models (corrective, preventive, and extensive). From a normative perspective, reviewing three democratic theories of citizenship, this paper claims that the most persuasive justification for this mode of loss is the 'all subjected persons' principle. The loss of citizenship of permanent expatriates thereby becomes part of a democratic theory linking habitual residence with possession and conservation of citizenship, with due respect for human rights principles.
\end{abstract}

Key-words

Citizenship - Nationality - Denationalisation - Expatriation - Emigration - Residence Abroad - Human Rights

\section{Funding}

This paper has received funding from the European Research Council (ERC) under the European Union's Horizon 2020 research and innovation programme (grant agreement No. [716350]).

\section{Acknowledgement}

I would like to thank Rainer Bauböck, Rutger Birnie, Ashley Mantha-Hollands, Liav Orgad, and the two anonymous reviewers for their useful comments. A previous version of this paper was presented at the Neuchâtel Graduate Conference of Migration and Mobility Studies 2019; I thank Jean-Michel Lafleur who discussed it, as well as Jean-Thomas Arrighi, René de Groot, and Lorenzo Piccoli for fruitful discussions during the session. Finally, Yvonne van der Does has been of great help in editing the paper. 


\section{Introduction}

In a globalised world, should nationality coincide with residence? Is long-term emigration compatible with the conservation of nationality? In a world where 'citizenship has become a primary instrument of global mobility' (Orgad, 2017, 350), these questions seem incongruous, if not outdated. Yet many states have a policy of cutting ties with long-term emigrants. The process is rather inobtrusive and understated (Honohan, 2015; Bauböck and Paskalev, 2015, 66-71.) It relies on the idea that the legal nationality could, at some point, no longer fit reality. When the bond between the individual and the state no longer exists as a result of a long-term expatriation and the absence of relations between them, the loss of nationality is declarative; it is a legal recognition of a factual situation. This is based on the premise that an 'obsolete' nationality - which does not correspond to a habitual residence - should be terminated.

This mode of loss of nationality appears in contradiction with the global transitions in the legal treatment of emigrants, especially of dual nationality (Spiro, 2016, 2019; Vink, Schakel et al., 2019; Harpaz and Mateos, 2019). Acquiring the nationality of the country of residence, while maintaining the nationality of the country of origin, is increasingly accepted by states and sought by individuals. Dual nationality enables states to turn their citizens into 'agents of influence' on foreign soil, thereby extending their political and cultural influence. For individuals, multiple nationalities enable them to increase their global mobility and economic opportunities, especially when it also involves citizenship of a European Union (EU) Member State. Acceptance of emigration and multiple nationalities seems deeply incompatible with the current policies of termination of nationality for long-term emigrants. However, many states including France, Mexico, Ireland or Pakistan allow multiple nationalities yet, at the same time, provide for the loss of nationality in case of permanent expatriation. Considering this puzzling situation, this paper investigates the functioning and the legitimacy of this mode of loss of nationality.

This paper explores, empirically and normatively, the loss of nationality of long-term residents abroad. It considers all modes of loss of nationality, i.e., the denationalisation of either first or later-generation emigrants, as long as the loss of nationality is based explicitly on long-term residence abroad. Non-acquisition of nationality at birth, if extraterritorial ius sanguinis is conditional upon prior domestic residence of a parent, is beyond the narrow scope of this paper, as in this case there can be no denationalisation since nationality was never acquired in the first place. The terms 'permanent expatriate,' 'long-term emigrant,' 'long-term resident abroad' will be used indiscriminately to refer to the same assumption that the individual is no longer genuinely connected with the state of nationality. The terms 'citizenship' and 'nationality' will also be used as synonymous, and both in the meaning of a legal bond between an individual and the state.

The first part examines empirical data from international and domestic laws. International law provides for a permissive regime, allowing states to revoke nationality in case of long-term expatriation, sometimes without any safeguards against statelessness. This practice appears to be widely accommodated in international law. Additionally, a comprehensive analysis of national legislation shows that many municipal laws provide for the loss of nationality after long-term residence abroad. From this data, a global definition and typology can be built by differentiating a 'corrective,' a 'preventive,' and an 'extensive' model of loss of nationality for permanent expatriates. The second part provides a normative justification for this mode of loss of nationality. The 'value of time' and the definition of a liberal and democratic paradigm can together strike a balance between the interests of both the emigrants and their state of nationality, regarding a loss of nationality through permanent expatriation. The loss of 
nationality thereby becomes part of a democratic theory linking habitual residence with possession/conservation of nationality.

\section{The Global Phenomenon of Denationalisation and Expatriation}

Laws allowing for losing nationality after long-term expatriation are not outdated. An empirical survey of international law shows that this mode of loss of nationality is legally recognized in leading treaties, with surprisingly few constraints to prevent statelessness. As for national legislation, data collected by GLOBALCIT ${ }^{1}$ show widespread allowance for loss of nationality following residence abroad, although the conditions for it differ considerably among states.

\section{International Law}

A consensus among states on the existence of an individual right of expatriation was progressively reached in the $19^{\text {th }}$ century (see Spiro, 2016). The emblematic 1868 US Expatriation Act states, for instance, that 'the right of expatriation is a natural and inherent right of all people, indispensable to the enjoyment of the rights of life, liberty, and the pursuit of happiness' (see Weil, 2012). This act came more than two centuries after Hugo Grotius proclaimed the principle that 'Nations leave to every one the Liberty of quitting the State' ([1625] 2005, vol. 2, 555). This principle was officially recognised in international law through the right to leave one's country proclaimed by article 13(2) of the 1948 Universal Declaration of Human Rights (UDHR) and article 12(2) of the 1966 International Covenant on Civil and Political Rights. However, the main concern of international law as regards long-term residence abroad was related to dual nationality, i.e., the accumulation of one nationality by birth in the state of origin and another nationality by naturalisation in the state of residence. In other words, international law was more concerned with preventing dual nationality than with the loss of nationality through long-term residence abroad.

It is only after the Second World War that international law started to provide rules limiting the power of states to deprive someone of his or her nationality on the sole basis of expatriation. The only substantial obligations imposed on state legislation by international law were designed to prevent and reduce statelessness. From that perspective, international law grants states a wide degree of liberty - or imposes very few constraints - in dealing with expatriation. In his famous Report on Nationality, Including Statelessness, Manley O. Hudson $(1952,18)$ wrote that the withdrawal of nationality based on 'prolonged absence abroad [...] may be regarded as giving effect to the national's desire for expatriation.' So, an individual's free and clear desire to reside abroad leads to a weak claim for protection. Following this reasoning, the 1961 Convention on the Reduction of Statelessness specifically allows for statelessness as a consequence of longterm residence abroad in two situations: first, if after seven years of residence abroad, a naturalised person does not declare his or her intention to retain the nationality; second, if an individual born outside the territory has not taken up residence or registered in the state of nationality at the age of majority (articles 7(4) and (5)). The United Kingdom's representatives drafted these exceptions by amendment during the travaux préparatoires, probably using the 1948 British Nationality Act as a model, which allowed for the revocation of naturalised subjects after seven years of being 'ordinarily resident in foreign countries' (section 20(4)).

\footnotetext{
1 GLOBALCIT is an open access online observatory on citizenship laws and electoral rights at
} http://www.globalcit.eu. 
Thus, the 1961 Convention provided citizens with only minimal protection against statelessness in case of expatriation.

In European law, the recent trend has been slightly different. The 1997 European Convention on Nationality (ECN) explicitly recognises the 'lack of a genuine link between the State Party and a national habitually residing abroad' as an acceptable reason for a loss of nationality, either ex lege or by individual decision (article 7(1)(e)). However, such loss cannot render someone stateless (article 7(3)), which is a significant difference compared with the 1961 Convention. The explanatory report provides some useful clarifications, especially regarding the conservation of genuine links with the state of nationality, which can be proved via consular registration, application for identity, or formal declaration of will to retain nationality, without this list being exhaustive. In these cases, the link with the state is maintained through consular representation, which allows individuals to keep at least an administrative connection with the state. Here, one could say that the link with consular representation represents a fiction of extraterritoriality: the residence 'abroad' is suspended as long as the individual keeps a foot in a consulate. The recent 2017 Draft Protocol to the African Charter on Human and Peoples' Rights on the specific aspects of the right to a nationality and the eradication of statelessness in Africa contains no provision for the loss of nationality based on considerations of residency.

From the perspective of EU law a discreet mention in the Tjebbes case [ECLI:EU:C: 2019:189] (Pataut, 2019) is of great interest. In this judgement the Court of Justice of the European Union (CJEU) examined the cases of four women who lost their Dutch nationality, and therefore EU citizenship (the basis for the European review), after living more than ten years outside the borders of the EU in countries of which they were also nationals (one in Canada, two in Switzerland, and one in Iran). Although mobility is a core value of EU citizenship, the Court nevertheless ruled that it was legitimate for the Netherlands to protect the links with its nationals by making the preservation of nationality conditional upon habitual residence on Dutch soil, in line with international and European standards (see above). Even more interestingly, the Court specified that 'in so far as it is not apparent from the order for reference that the applicants in the main proceedings have exercised their right to free movement within the European Union, there is no need to answer the question with regard to Article 21 TFEU.' These few words suggest that loss of European citizenship through long-term expatriation must not apply within the EU territory, since as per article 21 of the TFEU, 'every citizen of the Union shall have the right to move and reside freely within the territory of the Member States.' It seems obvious that the loss of nationality of a European citizen after a permanent expatriation could inhibit freedom of movement within the EU territory. Would a Spanish citizen consider moving to Germany if he or she could, as a result, lose his or her Spanish nationality? Even if the movement is not impeded, it is nevertheless indirectly obstructed. Therefore, the loss of nationality after longterm emigration is probably an obstacle per se to freedom of movement within the EU and as such contrary to EU treaties. The solution, which has already been adopted by Dutch legislation, is to apply expatriation-based loss of nationality only to individuals residing outside the EU. In consequence, it is probably correct to state that, when it comes to a loss of nationality, the EU territory prevails over the territory of Member States.

To conclude, the guiding principle of international law is to prevent statelessness. As a result, international and European laws generally impose few constraints; states have long perceived loss of nationality after long-term emigration as a legitimate measure. 


\section{National Legislation}

Using GLOBALCIT's Global Database on Modes of Loss of Citizenship (Globalcit, 2017), I conducted a legislation survey in different states on the loss of nationality based on residence abroad. Among the 174 states in the database, 51 have this kind of legislation ( $29 \%$ of the total). Five variables were identified to compare the 51 cases of loss of nationality based on residence abroad: first, the existence of statelessness prevention mechanisms; second, the target population with respect to the mode of acquisition; third, the standards for the 'residence abroad' condition; fourth, the criteria for retaining nationality despite residence abroad; fifth and final, the procedure of loss, either 'withdrawal' or 'lapse.' Applying this deductive method, these five variables helped first to map legislation in the different states and, second, to identify inductive patterns.

The first variable is related to statelessness prevention. Thirteen countries do not provide for legislative safeguards against statelessness. This situation is not so surprising because, according to the 1961 Convention, loss of nationality through long-term emigration can legitimately lead to statelessness after seven years of residence abroad (in the case of naturalised citizens). None of these thirteen countries is a contracting party to the European Convention on Nationality which prohibits statelessness (see above). Accordingly, probably because of a common English origin or influence, legislation in India, Ireland, Jamaica, or Pakistan has adopted the same duration of seven years abroad as a threshold for revoking the nationality of naturalised individuals, even if it provokes statelessness - in full compliance with the 1961 Convention. By contrast, other countries, such as Belize and Ecuador, do not prevent statelessness and do not even seem to respect international standards as denaturalisation may occur before a seven-year residence abroad.

The second variable is the target population. In 31 countries, only naturalised individuals - in the broad sense, meaning all individuals who have gained nationality by other means than descent or territorial birth - can have their nationality revoked following permanent expatriation. Two striking exceptions should be mentioned, related to specific modes of naturalisation which do not involve residence. First, 'economic citizenship' in Belize, obtained through an investment scheme without any obligation of residence, is explicitly protected in the law from any loss through long-term emigration (article 20 of the Belizean Nationality Act). Second, Irish citizenship through 'descent' or 'association' (i.e., based on cultural affinities), which comes without any obligation of residence, is formally excluded from any loss following expatriation (article 19(1)(c) of the Irish Nationality and Citizenship Act). Nine other countries make no exceptions and target all nationals regardless of the mode of acquisition, which means that even citizens by birth can be affected. And finally, eleven countries target only citizens by descent born abroad.

The third variable is the evaluation of 'permanent expatriation.' What are the criteria for considering that a citizen has resided abroad for long enough to be no longer considered as a member of the community? For 35 countries, the factual evaluation is based on a certain time of continuous residence abroad varying from one to ten years. Most countries provide for a five-year (13) or seven-year (12) period, while a minority of countries have adopted short periods from one to four years. Sometimes, the threshold is even lower when the individual's residence is in the country of origin: in El Salvador, for instance, naturalisation can be revoked after five years of residence abroad, but after only two years when the individual's residence is in the country of origin (article 94 of the Constitution). Moreover, several states have established time limitations for this mode of loss of nationality: Egypt, for instance, provides for revocation only within five years following naturalisation and Libya within ten. In the rest of the states, several conditions apply. In the Nordic countries (Denmark, Finland, Iceland, 
Norway, and Sweden), the loss occurs at the age of 22 if a particular time of residence in the country has not been reached. In France and Guinea, it is surprisingly not the individual but rather his or her ancestors whose time of residence abroad is evaluated. In both countries, a citizen by descent born abroad loses nationality (after birth) if his or her direct ancestors have resided abroad for more than fifty years. Other states have not specified a definite amount of time, but rather standards associated with the foreign residence, for instance, a 'permanent residence' in the Philippines' laws, or a 'permanent leave' in Myanmar's. Finally, some states extend the area within which the residence is not considered as being 'abroad': Denmark, Finland, Iceland, Norway, and Sweden consider that seven years of residence in another Nordic country protect Nordic citizens from being considered 'abroad'; likewise, Lesotho does not consider residence in the 'Commonwealth' as being 'abroad'; Syria applies the same rule to 'Arab countries.'

The fourth variable, closely connected with the third, is the ability to retain nationality despite residence abroad. The law is pretty uniform across countries. Consular registration (frequently on an annual basis) and working in public service are the main justifications for retaining nationality. In many other countries asking for a legal document, such as a passport or an identity card, implicitly shows the intent to keep the nationality. Sometimes a formal request must be filled by the individual mentioning his or her will to retain nationality. For instance, in the Nordic countries, the government 'may' grant an authorisation to retain nationality on a discretionary basis. In France and Guinea, the nationality is kept if the individual still has possession d'état. ${ }^{2}$ Other countries, such as the United Arab Emirates, Yemen, Belize or Egypt, only state that the individual can retain nationality if she or he has an acceptable reason. Only Mexico, Myanmar, the Philippines, Thailand and Zimbabwe do not provide for any possibility to retain nationality once the threshold of residence abroad has been reached.

The fifth variable is related to procedure. Two types of procedure can be distinguished: 'withdrawal' and 'lapse.' The first one means that nationality is lost via a decision on an individual case made by a public authority; the second one that nationality is lost automatically or ex lege, i.e., by the sole operation of the law. In both cases, the loss is involuntary in the sense that it is not premised on an individual declaration or application. 34 countries follow a withdrawal procedure, while 17 adopt a lapse procedure. A withdrawal procedure raises the issue of discretionary power: on what basis does the public authority initiate the procedure? Legislation in some states provides for a basic standard justifying the loss of nationality: in India, the measure must be 'conducive to the public good'; in Pakistan, the deprivation must be 'in the public interest.'

To conclude, three general models arise from these variables, the first 'preventive,' the second 'corrective,' the third 'extensive,' each has a different goal. The 'preventive model' aims at prohibiting nationality from being transmitted without limits to generations of citizens born abroad; it stops the phenomenon of ius sanguinis ad infinitum. ${ }^{3}$ Nordic countries generally adopt this preventive model but nationality is only lost at the time of majority. By contrast, the 'corrective model' aims at rectifying ex-post the conferment of naturalisation to an individual

\footnotetext{
2 This means that the individual acts subjectively like a citizen and that he or she is perceived objectively (especially by the public authority) as a citizen.

${ }^{3}$ The goal of such prevention is also achieved through limiting the acquisition of citizenship iure sanguinis by later generations born abroad to citizens parents. The same goal can also be pursued by setting an age limit and residence conditions for the retention of such a citizenship or through provisions for the loss of nationality in case of voluntary acquisition of a foreign citizenship. In the latter case, transmission of citizenship iure sanguinis is interrupted when parents acquire the citizenship of their country of residence. Those two mechanisms are, however, beyond the scope of this paper.
} 
who no longer resides in the country. In most cases, past domicile as a condition for naturalisation of immigrants is a proxy for an expectation of future domicile. Immigrants who take up long-term residence abroad defeat this expectation and thus can be denaturalised under this corrective model. Commonwealth countries, such as Jamaica, India, Lesotho, Malawi, and Swaziland, still follow the (repealed) principle of the 1948 British Nationality Act and are emblematic examples of the corrective model. The 'extensive model' aims at generally protecting the effective connection between a state and its citizens. To achieve this comprehensive goal, this model applies indistinctly to first and later-generation emigrants. It is based on the assumption that moving one's permanent residence abroad sufficiently indicates the loss of a genuine link. This model does not discriminate between nationals by birth and naturalisation. Brunei, Indonesia, Laos, the Netherlands, and Myanmar follow this third model.

\section{Justifications for Loss of Nationality after Expatriation}

The relation between residence outside the country and conservation of a genuine link is not self-explanatory. Drawing on several principles of democratic theory, I consider that the 'all subjected persons' (ASP) principle provides a convincing justification for the loss of nationality after permanent expatriation, especially by adding further reflection on the specific question of time. I additionally investigate human rights constraints regarding this mode of loss of nationality, to strike a balance between democratic and liberal justifications.

\section{Normative Justifications}

What could be the normative justification for a theory linking nationality - and its preservation - with residence? The issue is connected to major questions in political theory: the definition of the demos, delineation of boundaries around the people, and inclusion in/exclusion from the community of citizens. Partly based on recent work (Bauböck, 2018), three principles offering different views on the relevance of residence in the state territory can be identified.

The first is the 'all affected interests' principle (AAI). Following this approach, Robert Dahl famously wrote that '[e]veryone who is affected by the decisions of a government should have the right to participate in that government' $(1970,49)$. This principle does not apply to territory and residence because many persons living outside a given territory are affected by collective decisions taken by the demos constituted within the territory; this principle deliberately 'ignor[es] boundaries both of space and of time' (Goodin, 2007, 55). Expatriation cannot be associated with the absence of an 'affected interest' because the interests of individuals are essentially 'nonterritorial' (Lansbergen and Shaw, 2010, 66). As correctly stated by Sarah Song, this principle is over-inclusive because it extends to a 'great many people outside both the official membership/citizenship boundaries and the territorial boundaries of that state' (2012, 50). Territory, residence and emigration are thus of little help to define 'affected interests.' Therefore, the AAI principle cannot be used to justify the loss of nationality through long-term emigration. Territory should be rejected as a basis for nationality inclusion and/or exclusion because the relevant interests can remain affected notwithstanding residence abroad.

The second is the 'all citizenship stakeholders' principle (ACS), which 'focus[es] on the relations of individuals to a particular political community rather than to a government and its decisions' (Bauböck, 2018, 39). The ACS principle not only asks 'who' should be included, but also 'what' they should be included in. Who is a stakeholder differs according to the different type of the political community of reference, which include regional unions of states such as the EU, independent states, and local municipalities. This difference matters when it 
comes to residence: 'the [ACS] principle itself does not tell us whether residence in a territorial jurisdiction is a necessary or sufficient condition for holding a stake in its self-government and having therefore a claim to citizenship' (64). Each kind of polity has a corresponding 'membership character': derivative-based for regional polities; birthright-based for independent states; residence-based for local polities. Even if 'birthright character' does not prima facie provide a good argument for linking residence with nationality within a state, loss of nationality through permanent expatriation is nevertheless compatible with the ACS principle. Indeed, when dealing with loss of nationality, Bauböck (69) argues that the state's membership character precisely allows for the termination of ius sanguinis after several generations abroad: 'It is more consistent with the birthright character of national citizenship to let it expire for the distant descendants of emigrants through non-acquisition at birth instead of depriving first or second generation holders of this status on grounds of long-term residence abroad and acquisition of a foreign citizenship.' Bauböck's interpretation of the ACS principle supports the idea that later-generation descendants of emigrants no longer hold a sufficient stake in their ancestors' country of origin to be included in the polity at birth. Bauböck makes an argument for conditional ius sanguinis (conditional upon residence) rather than proper denationalisation of permanent expatriates. This principle is thus very protective for individuals: Nationality is safeguarded for quite a long time, at least for the first two generations of emigrants. This principle is, therefore, too broad to cover loss of nationality after long-term emigration, which could target first-generation emigrants (for instance in the corrective or extensive models; the ACS remains, however, able to justify the preventive model [see above]).

The third principle is the inclusion of 'all subjected persons' (ASP). Following this approach, all those who are subject to the coercive powers of the state must have control over it if the exercise of these coercive powers is to be legitimate. In other words, 'the demos is composed of those who share a wide range of multiply reiterated interdependencies, which have been significantly shaped by their subjection to a common authority' (Honohan, 2018, 150). This principle is closely connected to the democratic regime because subjection generates claims for citizenship inclusion: "If they can act collectively as citizens they may be able to determine their future - to be part-authors, if not wholly in control, of their lives.' (ibid.) Put differently by Habermas $(1996,120)$, '[t]he idea of self-legislation by citizens, that is, requires that those subject to law as its addressees can at the same time understand themselves as authors of law.' Thus, because subjection to the authority is nothing else than residence under the jurisdiction of this authority, the ASP principle suggests a strong link between nationality and residence.

Some authors suggest that foreigners residing outside the territory can also have a claim for inclusion as being subjected to the state's coercion, such as foreigners subjected to immigration control policies (see, e.g., Abizadeh, 2008). However, I will reject this view, considering that even if coercion exists, individuals remain free to escape it, which is a difference in nature and not in degree - from coercion exercised over individuals residing within the borders (Song, 2012, 52-53). As correctly stated by David Miller, "being prevented from doing what you would most like to do does not transform the case into one of coercion" (Miller, 2010, 117), because the autonomy of the individual is not directly at stake. Consequently, if subjection to a state's authority within its borders generates a claim for democratic inclusion, the absence of subjection could conversely support a claim for democratic exclusion. ${ }^{4}$ The perspective has

\footnotetext{
${ }^{4}$ I do not support the principle of disenfranchisement of external citizens as a way to solve this democratic issue. Political rights are at the core of the citizenship status, just like territorial and protection rights, and therefore should not be, in principle, separated from it. I favour the recent Frank v. Canada case ruled by the Supreme Court of Canada (11 January 2019, 36645) stating that 'citizenship, not residence, defines our political community and
} 
changed. The claim for inclusion entitles individuals to have control over the coercive power of the state, whereas the claim for exclusion entitles states to prevent the inclusion of individuals who have permanently removed themselves from state subjection. In other words, an individual who is not subject to the law should not be one of its (presumptive) authors and, thus, should not have a claim for acquiring or retaining citizenship. The 'all subjected persons' principle presents the strongest argument for justifying the loss of nationality through permanent expatriation. Subjection to the state's authority/coercion is the key for justifying that nationality should be closely connected to the territory, both for inclusion in and exclusion from the demos, based on democratic theory.The ASP principle's justification for denationalising expatriates, however, needs further specification if it is to offer workable guidelines regarding loss of nationality through long-term residence abroad. Democratic inclusion does not begin at the very moment an individual is subjected to state authority; similarly, democratic exclusion cannot operate as soon as a citizen has left the reach of state authority. Time - and its flow - are necessary for the 'reasonable trade-off' (Owen, 2012, 148) between the democratic legitimacy built on subjection to the state authority, and a political community's need for stability. We can draw on Elizabeth Cohen's insight that 'rights derive not just from who we are and where we are but also from when we are' $(2018,5)$. Time presents an instrumental and a representational value: It respectively shows a process and works as a symbol (ibid., 99-103). So, what is the correct amount of time that shows both quantitatively and qualitatively that an individual has lost his or her subjection to the state authority? The question is surprisingly rarely discussed by theorists, as normative reflections mainly address the inclusion of long-term immigrants (see, e.g., Rubio-Marín, 2000) or the non-inclusion of transients (Dahl, 1989, 129; Owen, 2012, 146147), rather than trying to formulate an explanatory theory of exclusion. In recent work, however, Iseult Honohan carefully acknowledges that '[1]oss of ties understood as the substantial absence of relationships of interdependence and independence of the jurisdiction could be a (...) justified ground [for the revocation of citizenship]' $(2019,13)$. In this respect, the author considers that 'only those who have never been territorially subject to the jurisdiction of the state might be considered to come under such provisions' (ibid.).

The question of time is accordingly crucial: what is a 'permanent' expatriation? Does 'permanence' fit with the disappearance of a previous subjection to state authority, or only concern the absence of any subjection? In the first case, the first-generation emigrant could be deemed a permanent expatriate; in the latter case, only born-abroad emigrants - second (and subsequent) emigrant generations - could be considered permanent expatriates. Unlike Honohan (2019), I do not see any theoretical argument for restricting loss of nationality to those who have never been subject to the state's jurisdiction, i.e., to the sole born-abroad emigrants. I agree it is unlikely that, from the first-generation of emigration, individuals will already cease to belong to the 'web of reiterated interdependencies' (Honohan, 2018, 151) that shapes the demos. Yet, the case of an individual cutting all the ties with his or her country of nationality is imaginable and cannot be restricted to born-abroad generations of emigrants. The ASP principle, linking residence with subjection to coercion, provides the most persuasive normative justification for a state's claim for exclusion, without any theoretical restriction to a particular generation of emigrants. ${ }^{5}$

underpins the right to vote' (see, among many others, Bauböck, 2007; Arrighi and Bauböck, 2017). I support, reciprocally, the strongest liberal standards regarding the loss of citizenship (see below).

\footnotetext{
${ }^{5}$ The question of generations is more related to human rights considerations, especially through the checking of
} the principle of proportionality (see below). 
Accordingly, being a resident abroad for a certain time seems a relevant factual context for evaluating the permanent expatriation of an individual. Whilst I recognise the arbitrariness of the choice of a particular time period, I want to put forward a possible length of time corresponding to a long-term emigration - i.e., long enough to legitimise the claim for exclusion. A good starting point could be the period of validity of an adult's passport, which is for a maximum of ten years. The absence of any contact of the individual with the consular authorities during ten years for renewing the passport could be an indication for the permanent character of expatriation. First, because the ten-year duration is consistent with state practice and international standards, which generally range from five to ten years (see above); second, because the absence of contact of the individual with the state authorities to maintain the passport's validity demonstrates that the nationality is no longer used to travel, to vote, or to provide proof of identity, for instance, and therefore has become obsolete. The lack of a formal document which entitles the individual to vote and to return to his or her country is thus indicative of the impossibility to engage in 'the practice or even the open possibility of collective public interaction' (Honohan, 2018, 150) within the demos. This ten-year period without making contact with public authorities shows both the disappearance of the subjection to state coercion and the independence from the demos, and then sufficiently qualifies the claim for exclusion.

However, one should acknowledge, on the one hand, that not every state possesses a worldwide consular network and, on the other hand, that the state could be tempted to manipulate consular procedures to make renewal impossible or more difficult in order to cause loss of nationality. The ten-year delay and passport renewal are, therefore, no 'panacea.' Consequently, to prevent both a physical impossibility to reach the consulate and any manipulation by the state (which should not revoke an obsolete nationality as a punitive sanction for individual actions), it seems reasonable to establish that no emigration should be deemed permanent if the individual subjects himself or herself to the authority of the state of origin within the ten-year period, and in this way revitalises the claim for citizenship. As is the case in the vast majority of countries (see above), securing a connection with the state while residing abroad should prevent any loss of nationality. In the particular context of maintaining a nationality, it seems reasonable to consider that setting a foot on national territory (at least) every ten years physically, which includes (by legal fiction) the premises of the embassy or the consulate, should stop the lapse of time, both rationally and symbolically (Cohen, 2018, 102). ${ }^{6}$ This idea of revitalisation is crucial. I do not support that (re)taking up residence in the national territory for some period shall be necessary and the only possibility for conservation of citizenship. Conservation differs by nature from acquisition. Once admitted to the club (Weil, 2011, 625), citizens should presumptively be considered as maintaining the material conditions of their belonging to the demos. Accordingly, the only evidence to the contrary is the total lack of contact with public authorities within a ten-year period, establishing not only the absence of subjection to state authority but also the independence from the political community.

To conclude, the ASP principle provides the most comprehensive, and persuasive, framework to justify the loss of nationality of permanent expatriates. To further contribute to the discussion, I have offered some precisions regarding the question of time and its evaluation. The risk is now, from a liberal perspective, that this theoretical framework alone leaves the

\footnotetext{
${ }^{6}$ The flexible character of this rule should, however, put the burden of proof on the individual. Conclusive evidence could be, for instance, any administrative action (passport renewal, birth certificate application, consular registration, etc.) or private evidence (statement of facts of a judicial officer establishing the physical presence).
} 
status of citizen too insecure. In that respect, human rights considerations must be considered as part of a coherent justification of this mechanism.

\section{Human Rights Considerations}

The aim is to propose human rights guidelines that deal with citizens confronted with long-term emigration and loss of nationality. Safeguards apply to loss of nationality through expatriation as to any other mode of loss of nationality. The international standard, in this case, is the prohibition of arbitrariness, in line with the provision of article 15(2) of the UDHR: 'No one shall be arbitrarily deprived of his nationality' (among many others, see Marchadier, 2018; Tunis Conclusions, 2014; Brandvoll, 2014; Van Waas-Hayward, 2008). Several principles (procedural and substantive), based on international human rights instruments and case-law, can be highlighted. I will also partly base my analysis on previous work by the Involuntary Loss of European Citizenship (ILEC) Guidelines Project (Carrera Nuñez and de Groot, 2015). These ILEC guidelines establish seven principles dedicated to the loss of nationality based on residence abroad: (a) statelessness prevention; (b) inapplicability to European citizens in case of residence within the EU; (c) non-discrimination between naturalised and birthright citizens; (d) ability of the citizens to make use of all relevant circumstances to prove the existence of a link with the state; (e) withdrawal procedure based on the individual's decision, rather than automatic loss; (f) equal acceptance of a declaration or an application for a passport as a proof of the will to retain nationality, if nationality can be retained while residing abroad; $(\mathrm{g})$ distinction between the first and second generation born abroad for ensuring the proportionality of the measure. These principles are in line with the latest developments in the liberal evolution of nationality in the European Union. They can provide a basis for analysing human rights constraints connected to nationality revocation in the case of residence abroad.

The first issue here concerns the procedural safeguards. This mode of loss of nationality, as any other mode, should be provided for in the law and be accessible and open for administrative or judicial review (Tunis Conclusions, 2014). The only (and major) question that remains is what procedure states should use to deprive someone of his or her nationality: automatic loss or withdrawal? The withdrawal mechanism implies a certain degree of discretionary power for the state to decide whether or not it will choose to initiate the procedure of loss. Rainer Bauböck and Vesco Paskalev have provided convincing arguments from a liberal and individual perspective that, in such a case, discretionary power is paradoxically a safeguard, for two reasons: 'First, only a positive action by the authority can bring about the loss of citizenship and the authority may be unwilling or lack the resources to take such action. Second, even if the authority decides to withdraw, the person concerned is more likely to find legal remedies against withdrawal compared to a situation where the same conditions lead to ex lege loss' (Bauböck and Paskalev, 2015, 69). I agree with this view. Even if the ex lege procedure protects prima facie equality and impartiality as no proper decision is involved, this procedure ultimately undermines the protection of the individual; by contrast, the assessment of the desirability of the withdrawal by the public authority makes room for substantive human rights considerations.

The second issue, closely connected to the first one, concerns the substantive safeguards. In accordance with the 1997 European Convention on Nationality, which states that 'Each State Party shall be guided by the principle of non-discrimination between its nationals, whether they are nationals by birth or have acquired its nationality subsequently' (article 5(2)), a special and discriminatory regime targeting naturalised citizens, i.e., a 'corrective' model, or iure sanguinis born-abroad citizens, i.e., a 'preventive' model (see above), are not suitable within a liberal 
framework. ${ }^{7}$ In line with ILEC guidelines, however, "in the context of checking the proportionality of a deprivation decision, it is appropriate to distinguish between the first generation born abroad and further generations born abroad" (Carrera Nuñez and de Groot, 2015). Nationality revocation of the first-generation emigrant is indeed likely to question the principle of proportionality, as the social environment of this generation is probably still closely connected to the country of origin. The consequences on private and family life of the deprivation measure are, however, likely to decrease over born-abroad generations. The assessment of the principle of proportionality may benefit, inter alia, this objective evaluation of the generations.

Statelessness prevention should also be at the core of human rights protection. The safeguards against statelessness are essentially about protecting the individual; it is not just a formal solution that makes the possession of any citizenship an appropriate protection. Accordingly, the second nationality possessed by the individual should be the one of the country of residence (Hudson, 1952, 20), where the individual has a claim for inclusion due to subjection to state authority (see above). In other words, in order to be coherent with the ASP principle, the claim for exclusion from the state of origin should be closely connected with an individual's reciprocal claim for inclusion in the state of residence - citizenship is not "fungible" (Honohan, $2019,12)$. Perhaps an individual could take advantage of statelessness prevention to avoid losing a nationality after permanent expatriation. Mono-nationality could be used as a strategy to prevent the obsolescent nationality from being lost - especially when the individual is entitled to another nationality and (purposely) does not claim it (if it was accessible by marriage, for instance) or declines it (if it was accessible by conditional ius soli-birth and residence on the territory - for instance). One could imagine a system where safeguards against statelessness would decrease and finally disappear over born-abroad generations. However, such a system would be doubly in conflict with liberal principles: it would not only violate the general prohibition of statelessness but also discriminate between nationals on the basis of their place of birth. In conclusion and in accordance with the principles set by the European Convention on Nationality (see above), denationalisation after permanent expatriation should never lead to statelessness.

A final word about the right of the individual to enter his or her own country. Should the deprivation occur, this fundamental right protected by article 12(4) of the 1966 International Covenant on Civil and Political Rights could be of some help to map the perspectives of the individual towards his or her former state of nationality. First, it is essential to state that the formula 'his own country' is wider than 'country of nationality.' Following the famous opinion of the Human Rights Committee in the Stewart v. Canada case (CCPR/C/58/D/538/1993), this article 'embraces, at the very least, an individual who, because of his special ties to or claims in relation to a given country cannot there be considered to be a mere alien.' Second, in this respect, the loss of nationality after permanent expatriation should leave the individual with a 'quasi-citizenship' (Touzé, 2011) giving him or her a special right to (re-)enter the country of origin based on previous possession of nationality and socio-cultural affinities. This mechanism would be able to achieve a liberal regime linked to this mode of loss, meaning that every individual deprived of his or her citizenship after long-term residence abroad could maintain a residual right to (re-)enter his or her former country of nationality, and in fine to reacquire citizenship through proper residence.

\footnotetext{
${ }^{7}$ The Great Chamber of the European Court of Human Rights, in the case of Biao v. Denmark (24 May 2015, $38590 / 10$ ), has also ruled that 'eliminating the discriminatory application of rules in matters of nationality between nationals from birth and other nationals, including naturalised persons' could be seen as a 'European standard.'
} 


\section{Conclusion}

Is it legitimate in the $21^{\text {st }}$ century for an individual to lose citizenship after permanent expatriation? Asking what rules are acceptable or not for involuntary loss of citizenship questions the legitimacy of the delineation of a people's boundaries. Legitimacy is an ongoing process connected to history, political consensus, and legal norms. Empirical data confirm the topicality of this mechanism. International law provides for specific legal standards regarding long-term emigration and loss of nationality. Notably, the 1961 Convention on the Reduction of Statelessness formally authorises states to revoke nationality in specific situations of residence abroad, even if it results in statelessness. This demonstrates the consensus within the international society in favour of this mechanism. Only the 1997 European Convention on Nationality prohibits this mode of loss of nationality in case of statelessness but expressly specifies that loss of nationality in case of residence abroad is a legitimate option for European states. Globally, at least 51 states still possess legislation which provides in various ways for long-term emigrants' loss of nationality. Empirically, whether it is to reverse naturalisation given to an individual residing abroad (corrective model), to stop ius sanguinis ad infinitum (preventive model), or to generally connect habitual residence with conservation of nationality (extensive model), a substantial proportion of states continue to link loss of nationality with long-term emigration. I have argued that these solutions are normatively justified. According to the 'all subjected persons' principle especially, a long-term emigrant who is no longer subject to the authority of a state progressively loses his or her claim for democratic inclusion. But this mechanism should not apply without due respect for liberal principles, which are able to moderate the severity of this democratic and territorial-based exclusion system. Human rights considerations suggest a withdrawal procedure, giving room for the public authority and the judge to assess not only the proportionality of the measure, but also the full prohibition of statelessness.

What next? A more comprehensive study on the way denationalisation of long-term emigrants is implemented could highlight global trends among states. For instance, the GLOBALCIT database (Globalcit, 2017) shows that Ukraine repealed its legislation on loss due to permanent expatriation in 2001, Nepal in 2006, or Armenia in 2011, while Laos introduced it for the first time in 2004. Justifications for introducing or repealing legislation in recent years, as well as an in-depth study of administrative implementation and individual data, could be useful to identify trends and future evolutions. This would contribute to the general discussion about the relevance of the territory in nationality laws: First by establishing in abstracto the link between loss of nationality and long-term emigration on the one hand, and ius soli (either full or conditional) and ius sanguinis (conditional upon residence) on the other (two sides of the same territorial coin); second by comparing in concreto the strength of territoriality in nationality laws. Following the concise formula of Elizabeth Cohen $(2018,30)$ that 'time and territory are both implicated in the creation of political boundaries,' these boundaries should be explored beyond this paper. 
Bibliography

Abizadeh, A. 2008. "Democratic Theory and Border Coercion: No Right to Unilaterally Control Your Own Borders." Political Theory 36 (1): 37-65.

Arrighi, J.-T. and Bauböck, R. 2017. “A Multilevel Puzzle: Migrants' Voting Rights in National and Local Elections.” European Journal of Political Research 56 (3): 619-639.

Bauböck, R. 2007. "Stakeholder Citizenship and Transnational Political Participation: A Normative Evaluation of External Voting." Fordham Law Review 75 (5): 2393-2447.

Bauböck, R. and Paskalev, V. 2015. "Cutting Genuine Links: A Normative Analysis of Citizenship Deprivation.” Georgetown Journal of Immigration Law 30 (1): 47-104.

Bauböck, R. 2018 (ed.). Democratic Inclusion. Manchester: Manchester University Press.

Brandvoll, J. 2014. "Deprivation of Nationality." In Nationality and Statelessness under International Law, edited by Edwards, A. and van Waas, L, 194-216. Cambridge: Cambridge University Press.

Carrera Nuñez, S. and de Groot, G.-R. 2015. European Citizenship at the Crossroads. The Role of the European Union on Loss and Acquisition of Nationality. Oisterwijk: Wolf Legal Publishers.

Cohen, E. 2018. The Political Value of Time. Cambridge: Cambridge University Press.

Dahl, R. A. (1970) 1990. After the Revolution? Authority in a Good Society. New Haven: Yale University Press.

Dahl, R. A. 1989. Democracy and its Critics. New Haven: Yale University Press.

Goodin, Robert E. 2007. "Enfranchising All Affected Interests, and Its Alternatives." Philosophy \& Public Affairs 35 (1): 40-68.

Habermas, J. 1996. Between Facts and Norms. Contributions to a Discourse Theory of Law and Democracy. Cambridge: MIT Press.

Harpaz, Y. and Mateos, P. 2019. "Strategic Citizenship: Negotiating Membership in the Age of Dual Nationality." Journal of Ethnic and Migration Studies 45 (6): 843-857.

Globalcit, 2017. Global Database on Modes of Loss of Citizenship, version 1.0. San Domenico di Fiesole: Global Citizenship Observatory, Robert Schuman Centre for Advanced Studies, European University Institute. Available at: http://globalcit.eu/loss-of-citizenship

Grotius, H. (1625) 2005. The Rights of War and Peace. Reprint edited by Richard Tuck. 2 vols. Indianapolis: Liberty Fund.

Honohan, I. 2015. "Limiting the Transmission of Family Advantage: Ius Sanguinis with an Expiration Date." In Bloodlines and Belonging: Time to Abandon Ius Sanguinis?, edited by Dumbrava, C. and Bauböck, R., 32-34. EUI Working Paper RSCAS 2015/80.

Honohan, I. 2018. "Republicanism and the All Subjected Principle as the Basis of Democratic Membership." In Democratic Inclusion, edited by Bauböck, R., 143-158. Manchester: Manchester University Press.

Honohan, I. 2019. "Just What's Wrong with Losing Citizenship? Examining Revocation of Citizenship from a Non-Domination Perspective." Citizenship Studies, DOI: $10.1080 / 13621025.2019 .1700045$ 
Hudson, M. O. 1952. "Nationality, Including Statelessness.” Yearbook if the International Law Commission (II): 4-24.

Lansbergen, A. and Shaw, J. 2010. "National Membership Models in a Multilevel Europe." International Journal of Constitutional Law 8 (1): 50-71.

Marchadier, F. 2018. "Le Droit à une Nationalité au Service de l'Éradication de l'Apatridie." Journal du Droit International 145 (4): 1117-1132.

Miller, D. 2010. "Why Immigration Controls Are Not Coercive: A Reply to Arash Abizadeh." Political Theory 38 (1): 111-121.

Orgad, L. 2017. "Naturalization." In The Oxford Handbook of Citizenship, edited by Shachar, A., Bauböck, R., Bloemraad, I., and Vink. M., 337-357. Oxford: Oxford University Press.

Owen, D. 2012. "Constituting the Polity, Constituting the Demos: on the Place of the All Affected Interests Principle in Democratic Theory and in Resolving the Democratic Boundary Problem." Ethics \& Global Politics 5 (3): 129-152.

Pataut, E. 2019. “Quand la Cour s'Empare de l'Effectivité. Effectivité de la Nationalité.” Revue Trimestrielle de Droit Européen 3: 709-716.

Rubio-Marín, R. 2000. Immigration as a Democratic Challenge: Citizenship and Inclusion in Germany and the United States. Cambridge: Cambridge University Press.

Song, S. 2012. "The Boundary Problem in Democratic Theory: Why the Demos Should be Bounded by the State." International Theory 4 (1): 39-68.

Spiro, P. 2016. At Home in Two Countries: The Past and Future of Dual Citizenship. New York: New York University Press.

Spiro, P. 2019. "The Equality Paradox of Dual Citizenship." Journal of Ethnic and Migration Studies 45 (6): 879-896.

Touzé, S. 2011. “La 'Quasi Nationalité,' Réflexions Générales sur une Notion Hybride.” Revue Générale de Droit International Public 115 (1): 5-37.

UNHCR, 2014. Interpreting the 1961 Statelessness Convention and Avoiding Statelessness resulting from Loss and Deprivation of Nationality (Tunis Conclusions). Accessed December 7, 2019. https:/www.unhcr.org/uk/protection/statelessness/5465e2cb9/interpreting-1961$\underline{\text { statelessness-convention-avoiding-statelessness-resulting.html?query }=\text { Tunis } \% 20 \text { conclusions }}$

Van Waas-Hayward, L. 2008. Nationality Matters. Statelessness Under International Law. Utrecht: School of Human Rights Research Series.

Vink, M., Schakel, A. H., Reichel, D., Luk, N. C., and de Groot, G.-R., 2019. "The International Diffusion of Expatriate Dual Citizenship.” Migration Studies 7 (3): 362-383.

Weil, P. 2011. "From Conditional to Secured and Sovereign: The New Strategic Link Between the Citizen and the Nation-State in a Globalized World." International Journal of Constitutional Law 9 (3-4): 615-635.

Weil, P. 2012. The Sovereign Citizen. Denaturalization and the Origins of the American Republic. Philadelphia: University of Pennsylvania Press. 